\title{
André Scrima: Orality and Writing
}

\author{
AnCa Manolescu
}

Most if not all of André Scrima's texts are responses to different requests: academic or spiritual, public or private. Many of them issued from his speeches that different interlocutors or auditors recorded and transcribed. He even confessed that he never produced a text as an "author" who autonomously deals with a subject. His creativity turned into discourse only in relationship with the other, solicited by the other, in front of the other. What function or meaning did André Scrima attribute to his orality, which incidentally he never failed to mention in the published version of his texts? "Event of speech" arising from profound meditation on spiritual matters? Detachment of a spiritual traveller from the position of "author" and its production? Model of sharing the spiritual knowledge? Perhaps a model of tradition? My paper tries to analyse these possibilities.

Keywords: Hermeneutic as spiritual journey, spontaneity of speech, ruminatio of the Word, rhythm of investigation, participative audience

During his last stay in Bucharest (1993-2000), Father Scrima often accepted my request for articles to be published in various cultural or scientific magazines. Things always happened in the same way: I used to present the editorial theme to him and to suggest to him that he tackle a certain aspect related to it. A few days later, I used to record what sometimes was a dialogue and, more often than not, his presentation on the theme in question. After having edited the text, I sent it to him so as to decide the final form of the article. He made some observations or added either a note or a few lines in order to emphasize a certain idea. However, this was just the beginning. The text continued to go through other stages of revision until the submission deadline became very close. The final stage of accurate editing seemed to be of little interest to André Scrima.

He intervened - gently but insistently - in order to change something in the very final layout of the article before it went to press: a fine detail, a

\footnotetext{
* Anca Manolescu, Researcher in religious anthropology. Organizer of the André Scrima Archive at the New Europe College - Institute for Advanced Study, Bucharest. Str. Plantelor Nr. 21, Bucureşti, ancamanolescu@hotmail.com. Anca Manolescu is translator and editor of André Scrima's texts at Humanitas Editing House, Bucharest. Author of articles and volumes on André Scrima's thought and presence, among which Europa şi întîlnirea religiilor [Europe and the encouner of religions] (Iaşi: Polirom, 2005); Modelul Antim, modelul Păltiniş. Cercuri de studiu şi prietenie spirituală [The Antim model, the Păltiniş model. Circles of Study and Spiritual Friendship] (Bucharest: Humanitas, 2015).
} 
subtitle, a term replaced with a more particular one he found on the spot. Properly grasping the text printed in the volume was a sort of adventure. For Father Scrima the finite product certainly seemed to be important, yet less important than the never-ending unfolding of his thoughts and mode of expression.

André Scrima was always willing to answer all sorts of spiritual or intellectual requests, to muse on a certain topic proposed by his interlocutor if he found it compelling. He appropriated it and considered it a common good. He vividly and thoroughly committed himself to scrutinizing it. However, writing, he used to say in a somehow exquisite tone of voice, was very tiring. There was, for him, an awkward and boring difference between the rhythm of one's thoughts and that of one's hand. As a matter of fact, all those who shared their intellectual and spiritual pursuits with him regarded him with admiration, affection and deference. They expected more than a finite text from him. They expected the vivid manifestation of an intelligence that every time was able to cast the subject matter under scrutiny in a light coming from the zenith. ${ }^{1}$

I also edited the volume entitled Timpul Rugului Aprins (The Time of the Burning Bush) $)^{2}$, which took shape as an answer to philosophers Andrei Pleşu and Virgil Ciomoş, who proposed that Father Scrima evoke the "Burning Bush" Group founded at the Antim Monastery. In the "Liminary Remarks," he wished to reveal the manner in which the first chapter of the book came into being: tape-recorded meetings, transcribing, editing, etc. In the same way I obtained the edited form of the dialogue between André Scrima and Andrei Pleşu ${ }^{3}$ and the former's contribution to the volume penned by $\mathrm{F}$. Schuon. ${ }^{4}$

Thus, I became aware of a feature of his spiritual and intellectual work, which was fully revealed to me when I assembled the André Scrima Archive at the New Europe College - Institute for Advanced Study in Bucharest. Almost all, if not all his texts are answers to requests: academic and/or

\footnotetext{
${ }^{1}$ All the texts I will refer to in this article are stored in the "André Scrima Archive" at the New Europe College - Institute for Advanced Study, Bucharest.

${ }^{2}$ André Scrima, Timpul Rugului Aprins. Maestrul spiritual în tradiţia răsăriteană [The Time of the Burning Bush. The Spiritual Master in Eastern Tradition], preface by Andrei Pleşu, volume supervised by Anca Manolescu (Bucharest: Humanitas, 1996, 2000, 2010, 2012).

3 "Un test ultim al faptului religios" ["The Last Test of the Religious Fact"]. André Scrima in dialogue with Andrei Pleşu, text published posthumously in André Scrima, Teme ecumenice [Ecumenical Themes], volume supervised by Anca Manolescu (Bucharest: Humanitas, 2004), 104-138.

${ }^{4}$ Scrima, "Foreword" to Frithjof Schuon, Despre unitatea transendentă a religiilor [The Transcendent Unity of Religions] (Bucharest: Humanitas, 1994), 5-18.
} 
spiritual, public or private. Many of them are the result of recordings and transcripts carried out by interlocutors or listeners. It was he who said that he had never produced a text as an author who writes a work autonomously. $\mathrm{He}$ never made a list of his works and publications. His creativity turned into discourse only when perceived in relation to the other, when requested by the other. I would even say in front of the other.

This happened at a very early stage. As a young monk who went to India to pursue doctoral studies, he sent Father Benedict Ghiuş, abbot of the Antim Monastery, a long letter from Benares. Among other stages of his itinerary he gives an account of his contact with the Protestant universe at the Ecumenical Institute at Bossey, Switzerland and of his meetings with innovative Catholic thinkers in Paris. He speaks enthusiastically of how he received invitations to deliver speeches, to participate in dialogues and reflections on the Eastern tradition, monasticism and his experience at the Antim Monastery shared in intellectual circles, monasteries, universities: "It very often happened to me (in Switzerland and France) to give an elaborate talk in the morning, to deliver an exposé in the afternoon, to take part in philosophical discussions until late in the night." ${ }^{5}$ He was also asked to write an article on spirituality for Protestantische Real-Enzyklopädie. His other text L'avènement philocalique dans l'Orthodoxie roumaine was published in Paris, in Istina review, issue 3-4/1958. ${ }^{6}$ (He may have written these two contributions in his own hand). Encountering the others in the Spirit was what he enjoyed the most. This is why he probably was so adept at spontaneous orality, the lively discourse only prepared by some notes, a discourse which aimed to become a dialogue, a path of joined research that was open to vertical interventions from above. At some point, in France he was invited to give a talk to the sisters of the Apostolic Carmel without having been warned about it:

I tried on the spot (my emphasis A.M.) a kind of common meditation (... that is, not only an exposé, but also questions from a participative audience and the sharing of mutual personal experience); it was a divine joy for me. ${ }^{7}$

The joy of dialogue was probably not solely due to André Scrima's sprightly intellectual and spiritual temperament. It also preserved something from the atmosphere - I would say from the "discipline" - of the Antim Monastery

\footnotetext{
${ }^{5}$ Scrima, "Letter to Benedict Ghiuş (Benares, 6 August 1957)," published posthumously in Scrima, Ortodoxia şi incercarea comunismului comunismului [Orthodoxy and the Trials of Communism], volume supervised by Vlad Alexandrescu (Bucharest: Humanitas, 2008), 406-7.

${ }^{6}$ Published in Romanian in Scrima, Ortodoxia, 229-324.

${ }^{7}$ Idem, "Letter to Benedict Ghiuş," in Scrima, Ortodoxia, 403.
} 
Group, where the informal conversations of the members were heavily nourished by culture, sharpness of mind and commitment to faith.

In any case, most of the texts left by André Scrima took shape as answers to various requests. Also, most of them derive from an oral version, be it a conference, a text commentary, an academic lecture, an intervention in a debate, a public or private seminar or a speech given in front of a group or a person. In many of them, André Scrima insists on mentioning the status of the text or to track the "route" of its publication. In the lectures he gave at the Saint-Joseph University, Beirut, the mention on the first page reads as follows: "Student notes unrevised by the author". Comentariul la Evanghelia după Ioan [Commentary on the Gospel according to John] is preceded by this "clarifying Foreword":

Here is, in just a few words, the simple story of this text. It has been a few years since, in the monastic community from Deir-elHarf (Lebanon), we opened the Gospel of John in order to start doing a commented "inner" reading of it. Everything happened live, in a loud voice while one of the brethren, well-versed in both languages, was dealing with the complete transcription in Arabic of the talk given in French. This paved the way for the first 400page volume (covering chapter 1-17) that was published in Beirut in 1988 and was followed by further editions.

The circumstances allowed us to resume our work on the last chapters of the evangelical text (chapters 18-21) at the end of 1985 and the beginning of 1986. Throughout the twelve days of intense, lively reading we followed the same method, this time taking advantage of tape-recording. No single text in French was elaborated in advance (except, of course, the notes meant to guide the commentary) so that the present text in French derives from direct-totape recording, in parts revised thanks to the translation in Arabic that was made while the oral talk was being delivered. The quite difficult route of the text - largely - accounts for the inevitable repetitions or even the flawed mode of expression which we could not fully amend because of time constraints. There is, however, a fundamental fact that is at stake: once it has been opened "towards knowledge", the book of Saint John can no longer be closed, just as the knowledge it imparts is never to end, either. ${ }^{8}$

The written testimonies and memories of some close friends show that Father Scrima did not shy away from adopting the foregoing "collaborative"

\footnotetext{
${ }^{8}$ Scrima, "Clarifying Foreword," Comentariu integral la Evanghelia după Ioan [Complete Commentary on the Gospel according to John], translated from Arabic by Monica Broşteanu, translation from French by Anca Manolescu (Bucharest: Humanitas, 2008), 7-8.
} 
manner: the spontaneous discourse, insofar as he is concerned and its transcription, insofar as his listeners' are concerned. He considered the method as self-evident even in front of some friends, of some "equals," of some "superiors." For instance, in the typewritten version stored in the New Europe College's Archive, the text entitled Religions de salut et salut en Jésus-Christ' is preceded by a "Note":

On February $8^{\text {th }}$, 1985, Father Joseph Moingt SJ presented in Beirut a report entitled "Religions of Redemption and Redemption in Jesus Christ". The report stirred a debate which enabled Father Moingt to verbalize his reflection and make it complete.

Invited to comment on the text, Father André Scrima gave an improvised talk on May 29 ${ }^{\text {th }}, 1985$. We submit the following notes from the 6-hour long direct, unprepared commentary that was transcribed by Father Augustin Dupré La Tour. ${ }^{10}$

Here are a few passages from "Liminar" ["Liminary Remarks"] on the volume The Time of the Burning Bush:

The texts gathered in this volume (each one autonomous within its limits) are marked by a coherence that enables understanding to pass from one to the other. The reference point of the articulated meaning... is particularly unravelled by the reading and "vivid" interpretation of the Letter of the Foreign Pilgrim... The meeting of those brought together by the second text (the Antim Monastery Group), the then lived experience... are simply integrated in an axial tradition of which the last text is trying to speak, structuring it succinctly.

If this volume took shape... it is yet again the effect and outcome of a meeting. After many decades, while passing through Romania - in 1991 - between India and the West, I met Mr. Andrei Pleşu. Towards the end of the same year, I made acquaintance with Mr. Virgil Ciomoş in Paris. Upon returning to Bucharest for a longer stay, we owe to their request and the Terra Lucida collection our endeavour to embark in many meetings on the "enacted" hermeneutic reading of the previously mentioned document.

Tape-recorded, it is published in the final form thanks to the efforts of Mrs. Anca Manolescu, who supervised this volume... ${ }^{11}$

\footnotetext{
9 Text published posthumously in Romanian, in Scrima, Teme, 88-103.

${ }^{10}$ In a letter dated June 6th, 1985, Father Augustin Dupré La Tour s. J, Dean of the Faculty of Religious Sciences at Saint-Joseph University, Beirut, thanks Father Scrima for the commentary and informs him that the transcript will be sent to Paris, where Father Scrima had left after a short stop in Rome.

${ }^{11}$ Scrima, Timpul, 17.
} 
Why so many clarifications, why such a minute "framing?", I asked myself many times when reading these and other related passages. I found them strange, pretentious, prone to stressing his own person in an excessive way. But it was not just that! It is true that Father Scrima was sometimes fancy, affected and caught up in self-admiration. However, insofar as spiritual matters were concerned, he treated them with trans-individual rigour and devotion. Therefore, why did he insist so much on describing the circumstances in which the text was produced?

Maybe to point out its status as an "event." Not a mere cultural event, but one placed under a higher light. An event shared by the speaker, the interlocutors and the audience alike, an event that encompassed all of them.

I have referred to the features that characterized "the event," according to André Scrima's notes. It was "provoked," it answered a concern posed by the other. When André Scrima thought that the theme and the one who came up with it were weighty enough, his readiness and the quality of his readiness were outstanding. He could accept responsibility for an interrogation even more ardently than its initiator.

Secondly, "the event" consisted in a direct, unprepared speech, nourished only by what reflection, meditation and experience had gathered inside the speaker over time. It occurred in a "now" of the meeting where another contributor, "the wholly other" one, called on by the very concern of all those reunited could arise.

Lastly, "the event" was carefully situated: it took place at the intersection of some routes, maybe of some destinies. Free from the boundaries of any place, André Scrima, the traveller, met other people keen on the theme of the journey, potential travellers or people who just set off or peers following converging routes. It was not by chance that he often recalled spiritual travellers from other ages, itinerants whose filiations he joined in, perhaps trying to hand them down, to extend them. ${ }^{12}$

Given these features, what function and meaning assigned André Scrima to the event focused on orality?

\footnotetext{
${ }^{12}$ Of course, above all, I am referring to Father John the Foreigner, the pilgrim who handed down the tradition of the Hesychast prayer to his friends at Antim (see: Scrima, Timpul Rugului Aprins). The texts related to the contemplative tradition of Eastern Christianity (gathered in the volume Despre isihasm [On Hesychasm]).
} 


\section{Improvisation or ruminatio?}

I have dwelled on the oral character of his productions for so long that one might think that writing did not mean anything to him. Conversely, that was not true. A very large number of manuscript notes have been stored in the André Scrima Archive at New Europe College, Bucharest. He used to write on notebooks, on planners, on sheets, on envelopes, on strips of paper, on colloquium programmes, on invitation cards, on the edges of diary pages. He thus framed an idea, a poem, a prayer, a well-thought-out expression, an inner event, a thought, a theme. One can find elaborate notes that are a few pages long, which reveal both a legible and neat writing and a highly articulate and well-organized narration. Some of these notes are even resumed two or three times as if writing served to place, move forward and develop the theme within the researcher. Apart from them, there are other notes, written particularly in the second part of his life, which are on the verge of unreadability: they look like bits of unpolished writing, as if the idea that came to him had been too subtle (too mysterious?) to be clearly put on paper. Other notes display a superposed type of writing which is placed among and over other already written lines, becoming a welter of letters that are indecipherable for anyone but its author. Does it serve as a "trace" of an intellectual event? Is it only the mark of a meaning that does not let itself be extracted from where it is, from shining inwardness? Is it the ardent attempt at disclosing the tight knot of a thought?

Facing this wealth of texts, which vary in mode of writing, writing materials and style, one must admit that they are so typical of André Scrima: they stand for an ongoing act of intellectual-spiritual ruminatio.

As is well known, ruminatio is an authoritative term in the medieval contemplative milieu: it meant "to ruminate," "to chew" the divine word, on and on, in order for it to exude its substance, richness and meanings, to nourish and transform the contemplative's inner being. ${ }^{13}$ In fact, manducating the divine word, interiorizing it through "chewing" is a very old

\footnotetext{
${ }^{13}$ Here are a few references related to the theme: "Lectio divina," in Dictionnaire de spiritualité ascétique et mystique, fasc. LIX-LX (Paris: Beauchesne, 1975); Dom Jean Leclercq, L'amour des lettres et le désir de Dieu (Paris: Cerf, 1957), 72-73; Monica Sandor, "Lectio divina and the Monastic Spirituality of Reading," American Benedictine Review 40, no. 1(1989): 82-114; Matthieu Rougé, Doctrine et expérience de l'Eucharistie chez Guillaume de SaintThierry (Paris: Beauchesne, 1999), 205-7; Éric Méchoulon, Le Livre avalé. De la littérature entre mémoire et culture (Montréal: Presses universitaires de Montréal, 2004), 47; Giuglielmo Cavallo, Lire à Byzance (Paris: Les Belles Lettres, 2006), 105-7; Duncan Robertson, Lectio divina: the Medieval Experience of Reading (Collegville, Minnesota: Liturgical Press, 2011), 205-6; Orlando de Rudder, "Pour une histoire de la lecture," Médiévales 3, (Janvier 1983): 97-110; and, of course, Marcel Jousse, La manducation de la Parole (Paris: Gallimard, 1975).
} 
theme. It is frequently mentioned in the Jewish tradition. "This book of the law shall not depart out of thy mouth" (Josh. 1.8). "But the word is very nigh unto thee, in thy mouth, and in thy heart, that thou mayest do it" (Deut. 30.14). The conclusion is that this word concerns all levels of the being: utterance, deed and especially the "cardiac" knowledge within the core of the being. As such, not only does it have to be "chewed" through repetition and memorization, to be "digested" through research, study and meditation, it also has to come to be tasted - as will be said later - in "the palate of the heart." From the first Christian centuries, erudite hermeneuts and Desert monks have dealt with this "manducation of the Word". Prescribed by Leviticus 7.9, the tools used for preparing the offerings are read by Origen, for instance, as a hierarchy of the meanings of the Scripture and concurrently as the degrees of a "dietary" assimilation of the Word of God. The allegory he proposes is baroque yet no less suggestive. The hermeneute brings as an offering on the "grill" the "blatant," immediately evident meanings; the "frying pan" stands for the meanings which "can be understood and explained if they keep being turned over many times"; the oven symbolizes man's heart, where the "most profound and mysterious" meanings "of the divine Scriptures" "are baked." ${ }^{14}$ From the inchoate understanding of the biblical word to the rational inquiry into its subtle meanings and to the mystery of the Word whose presence gets bigger and fully develops in the oven-heart, Origen sketches the function of the Eastern melete and the Western ruminatio, the complete effectiveness that the method is meant to achieve.

In: The Time of the Burning Bush, Father Scrima himself makes a reference to the monastic, contemplative manducation of the Book. Here he decodes the passage from The Book of Revelation 10.9-11, readily agreeing with all those who feed on the Meaning of Scriptures:

The Book proves to be as sweet as honey, agreeable, delightful, once it is assimilated by the brain, by the mind, by immediate understanding... But deep down, it displays its esoteric meaning which reveals itself to inwardness, to "the womb" - the place of ultimate assimilation... Here the meaning, the noesis turn bitter... The assimilation is no longer agreeable, easy, natural, exterior but tough, grave, painful. Knowledge, the "consumption" of the Scripture in its ultimate, inner, infinitely assimilable sense is indeed a serious act for he who lives by the Spirit. ${ }^{15}$

\footnotetext{
${ }^{14}$ Origen, Omilii la Levitic [Homilies on Leviticus], 5, 5, bilingual edition, introduction, translation and notes by Adrian Muraru (Iași: Polirom, 2006), 191.

${ }^{15}$ Scrima, Timpul, 90-91.
} 
I think it is appropriate to consider this function, this effectiveness of noetic "consumption" when we are trying to find the role of André Scrima's writing. I am not saying that, insofar as he is concerned, writing would exhaust the "ruminating" attitude towards spiritual themes. This very attitude stands for his way of being. Writing is nothing but a prop, an exercise, a means of research on/discovery/maturation of knowledge. Writing assists reflection, encounters the vertical axis of inspiration and marks the tracking of the paths of meaning. Relying on writing, the researcher grasps the hidden layers of meaning and lets himself be guided by them.

The fact that he assigned this function to writing is not groundless. Although he refers to other persons, the situations he mentions could very well be applied to him too. For instance, he recalls the case of his mentor, Sandu Tudor. When Sandu Tudor become a monk and later a priest under the name of Daniil, he even used to write in the altar, when not directly involved in the liturgical office. This probably was a way of participating more actively in the liturgical mystery. To fulfil the ritual and meditate on it through writing meant to understand the liturgical service as a way of knowing, as enacted theology. Through writing, Father Daniil was a participant in a twofold manner: he was inspired by the unfolding of the liturgical mystery and at the same time jotted down the meanings that the mystery brought in his mind, formulating them poetically or discerning them reflexively.

One can assume that writing fulfilled a similar function for André Scrima. It could act as a support for double understanding in which flashness of inspiration and elaborate thoughts worked together. What he received as a spiritual impulse left its mark on the lapidary, febrile free-writing put on paper: it was a private "code" which could induce meditation or maybe reflexive elaboration along the way. Reflection can thus "unfold" the spark that consciousness receives in a "folded" manner, synthetically, in a moment of clairvoyance.

Also, André Scrima mentioned the case of conscience of a well-known American Catholic monk, Thomas Merton (1915-1968). A man of letters, Merton asked himself whether writing - even the written spiritual meditation - can somehow nourish the author's ego, being thus at loggerheads with the monastic path. A Trappist monk consequently devoted to the life of silence, Merton was, however, urged by his superiors to add writing to silence, the former being an inward way of working that suited him well and could help him clear his mind and find his inner calm.

The fact that Father Scrima used to mention both cases seems very suggestive to me. From his point of view, neither the liturgical service, nor contemplative concentration defies the help and exercise of writing. On the 
contrary, it seemed to play a significant role in intellectual-spiritual "intussusception." This is a term Father Scrima liked very much. ${ }^{16} \mathrm{He}$ believed that "intussusception" matches with the way in which the Spirit works in man. The Spirit inserts His sap into the depths of the human being, in its secret centre. From there He raises it according to His own quality and assimilates it. The being needs to answer this subtle intervention through attention and contribution to the growth triggered within it. One may say that writing contributed to this endeavour to pay attention, to refine and "bake" the deep spiritual meanings under the influence of the Spirit.

On the other hand, I have brought enough arguments to show that André Scrima was (relatively) detached from the text as a finite product framed between its margins. The wealth of extended or sketchy notes that he preserved shows the stress laid on writing as ruminatio, rather than the expression of an author. After all, writing contributed to the richness of that inner repository, that space of intellectual and spiritual meditation from which the lively, spontaneous word emerged like an event.

Another aspect must also be taken into account, namely the fact that in the presentation of his texts André Scrima mentions, in one form or another, the theme of itinerancy and spiritual itinerants. It is mentioned so often that its occurrence inevitably makes it suggestive. Indeed, to lay emphasis on orality, on spontaneous discourse and to be in some way unconcerned about preserving the uttered word is an attitude which fits with the condition of the "traveller." An "author" is someone who says "I" and makes proof of this "I" through his texts. The author is expressed and somehow "tied" to them. The spiritual traveller - André Scrima often says that - does not offer "finite products." He offers traces, path markers meant to guide one in a specified direction and afterwards to be left behind. ${ }^{17}$ Was the statement that his edited texts had certain flaws just an excuse? Or is it still an allusion to the status of itinerant which - programmatically - detaches him from all that might be framed, including the finishing touches on a text before its publication? Once he created the "event" - through the lively word -, the traveller takes a distance from its "objectification"; he moves on, leaving the participants to decide whether or not to put on paper what has been uttered during the meeting.

\footnotetext{
${ }^{16} \mathrm{He}$ mentioned it, for instance, in a private seminar: "There is a beautiful word which comes from biology and was borrowed by philosophy: intussusception. To rise, to assume from within."

${ }^{17}$ This is the core theme of the volume Timpul Rugului Aprins, particularly of the chapter entitled "Lectura hermeneutică a scrisorii Părintelui Ioan cel Străin” [“A Hermeneutic Reading of the Letter of Father John the Foreigner"].
} 
One more remark: the "event" of orality and of the reunion around it is vertical, lively, based on dialogue. It is unrepeatable to some extent. "Will the written text be able to convey its vibration and enter into dialogue with other seekers?", Socrates had already wondered in Phaidros. André Scrima makes every effort to preserve the written text in the realm of the orality that generated it. He invites the reader to become aware of this realm, to become part of it. This is why he probably gathers the otherwise extremely minute indications about the emerging moment of the word, of the situation in which it was uttered.

\section{Repetition: a flaw or a method?}

Basically, the fact that André Scrima quite often expressed himself by word of mouth, and only due to a certain request shows that he was not interested in bringing his own thought into the open. He preferred to lay stress on the other, to address to a well-configured interlocutor whose condition, background and spiritual-intellectual expectations were well known to him. Father Scrima's texts prove that he adapted - or tried to adapt - his discourse, tone, manner of research to those who listened to him. In the preamble to the published texts he happens to evoke, sometimes at length, the profile of these people. ${ }^{18}$ Knowing the other meant knowing what research route they could embark on together. It meant proposing to the other a suitable way of reflecting which in no way marred the speaker's style.

Listening to André Scrima was an adventure. It meant being displaced from the too explicit fluency of thought, being charmed by radiant subtleties, probing the clues, levels and wide array of meanings he revealed, which poured over the audience. The fluctuating discourse, the repetitions, the innuendoes, the surprising associations and the leaps from one point to another required sharp attention, which at some point ran the risk of being shattered. You were concurrently captivated and befuddled, bewildered by the beauty of meanings and puzzled by the intricacies that engulfed them.

A man of the Church denounced André Scrima's repetitive patterns during a public meeting concerning the Father's presence and thinking. "He

\footnotetext{
${ }^{18}$ In 1999, I asked him to contribute to The Museum of the Romanian Peasant Anthropology Review with the interpretation he had made years before about two Christian art pieces included in the De Menil collection, Houston, Texas. Father Scrima had a strong desire to preface the text with an ample evocation of the De Menil family, particularly of Mrs. Dominique De Menil and the work of the De Menil Foundation, that is, the promotion of modern sacred art and the fraternal meeting of religions (see: "Deux pièces d'art traditionnel: regards et déchiffrement," Martor. Revue d'Anthropologie du Musée du Paysan Roumain 4 [1999]: 37-54).
} 
repeats himself; he endlessly repeats himself...," said that priest. It is true that, while reflecting, Father Scrima repeats a certain word or statement many times - even word by word sometimes. Yet the repetition of a phrase or idea in his discourse is a characteristic of orality, of direct, unprepared and unrevised speech. Yes, there is an evident repetitive pattern in many of André Scrima's speeches. But is it a flaw? We cannot speak about dull, automatic, meaningless repetition that is either soporific or exasperating. To my mind, Father Scrima's repetitive pattern fulfils a few roles which I will try to explain in what follows.

First of all, repetition marked a rhythm of investigation. It appeared when a path of meaning had been followed and the thought had been recollected in order to carry on. The prevailing idea was resumed in order to "make the point" and to prepare the ground for the further interpretive route. Rhythm-generating repetition was actually badly needed for André Scrima's type of discourse. His ample asides and sometimes very "exotic" references made both research and the listener lose track of their place on the map of investigation. Derived themes and an extensive network of paths unfolded sumptuously and tended to become autonomous. The repetition of an idea or a key term placed marks in this scholarly and relishing unravelling.

However, didn't André Scrima follow the very structure of the commented text by having recourse to repetition? Didn't he emphasize the very rhythm of that text? The Hermeneutic Reading of the Letter of Father John the Foreigner begins with the statement that this testament-letter is "a progression determined by a very rigorous inner rhythm" and that its text is methodology in the basic sense of the word met'hodos: "pursuit along and together with the way," where "inscribing the word with a route is what matters, not the discursive aspect or conceptual concatenation." ${ }^{19}$ Well, the status of route, of methodology is mentioned, illustrated, explained in many parts of the commentary. But every repetition is related to a different aspect of methodos, another milieu where its symbolism is imprinted. From that "Scripture reading methodology" and "grammar of confession," typical of contemplative prayer, ${ }^{20}$ to "the beginning" of John the Foreigner's "road," 21 to the notion of "trace" as grammé - "a sign meant to be decoded" - which "reveals a new space that can only be accessed by the traveller who deciphered the sign," 22 to the renewal of the one who decodes/tracks the traces

\footnotetext{
${ }^{19}$ Scrima, Timpul, 25-26.

${ }^{20}$ Ibidem, 38-39.

${ }^{21}$ Ibidem, 51.

${ }^{22}$ Ibidem, 72.
} 
(grammai) of the path to eternity, ${ }^{23}$ to the sumptuous interpretation of the Book and icon as a network of signs (grammai) that need to be assimilated in their unfolded and folded context ${ }^{24}$ and up to "the Apocalypse that yet again proposes the book as a trace that must be sought, understood and followed," 25 the "methodology" theme appears on and on. But it reappears so as to evoke a constellation of meanings that are subtly related through their depth. It appears and reappears to point out the "notes," the variations, the rhythm of the spiritual path, the impetus, its tepidness and revival, its endless dynamics. It appears and reappears in order to prove that the inner itinerary and the hermeneutic itinerary overlap, that the spiritual pilgrim and the commentator of its route go the same way.

In André Scrima's commentary, The Gospel of John stands for yet another path. It is, of course, Christ's path, the path of His act and revelation, but also the path of the composition proper, where "everything, every word is imprinted, marked. Paying attention to the marks scattered throughout the fabric of the text is not an easy task." ${ }^{26}$ Here again, the commentator lays emphasis - repeatedly - on "the evangelical path that we will follow until the end." ${ }^{27}$ Here again, he insists on "the inner coherence of the Text, on its - admirable - cadence and rhythm." ${ }^{28}$ The often repeated reference to the structure and rhythm of the Text - which the commentator must detect and throw into relief - plays a well-defined role: it urges the interpreter and the listeners to approach the Gospel as an inner hermeneutic and noetic path. It sets them in motion in accordance with the rhythm of the Text. In this case, repetition is not discouraging, boring, "stagnant"; it is restorative, an incentive for spiritual intelligence. It trains the mind to reach a wide-open and inexhaustible horizon of meaning.

Whereas the repetitions related to the style of the Gospel are many, thematic repetitions are even greater in number. I would only remind you that Father Scrima insistently speaks about John's "theological vision," about "the openness theology" of his Gospel, about John as a theological witness, about the Cross which, in John, is theological. However, these are not just simple statements. They are remarks made in tight connection to the text, confirmed by the concerned episodes and John's formulation of them. They

\footnotetext{
${ }^{23}$ Ibidem, 73.

${ }^{24}$ Ibidem, 82-85.

${ }^{25}$ Ibidem, 89.

${ }^{26}$ Scrima, Comentariu, 326.

${ }^{27}$ Ibidem, 361-62.

${ }^{28}$ Ibidem, 339.
} 
are stirred by the fabric of the text. By repetition, the commentator draws attention on the simultaneous presence of two universes in John's Gospel: the concrete, geographic, historical, socio-religious one and the divine one, "the place where Christ descended and where He returns." Each time, John underlines the tension between the two worlds and the vertical openness between them which is created by Christ. Repeatedly invoking the theme of "the theological" only means calling the audience's attention to the dominant structure of the Gospel of John, which makes it peculiar.

Apart from rhythm, repetition serves to highlight the organicity of a theme, the hidden structure that supports it. What does organicity mean? In the words of André Scrima, it "means a sort of vibrant and dynamic totality whose order comes from within." ${ }^{29}$ André Scrima uses repetition in order to grasp the depth of meanings and thus to reach this inner root. Through repetition, the coherence of the topic, its hidden links become obvious. This is what happens when André Scrima insists on the theme of the Day One and Octave (in the lectures on The Byzantine Liturgy of the Pentecost and in Commentary on the Gospel according to John). The in-depth, "drill-down" analysis of the theme is carried out by recourse to repeated and enriched explanations, liturgical and patristic quotations, comments that stress various aspects. As regards the listeners, repetition can bring about a change in perspective through accumulation; they become conversant with the reading and rhythm of inwardness. Briefly, repetition assists the appropriate research into the theme. Because "if we want to really grasp the inner meaning and authentic life of these liturgical traditions, we must adopt an organic approach as much as possible so as to see how they are ordered from within." 30

Organicity is defined by yet another quality which stems from that radiant inner centre: it characterizes a vibrant totality. An "organic" theme looks like fabric. If you reach any of its points/aspects, the others respond and readily join that point or aspect. If the research method is "organic," the researcher must also underline the inner centre and the totality he creates. When properly employed, repetition helps research, which concurrently moves vertically and integratively.

\footnotetext{
${ }^{29}$ Scrima, "Liturgica bizantină a Cincizecimii. Analiză structurală şi tematică" ["The Byzantine Liturgy of the Pentecost. Structural and Thematic Analysis"], published posthumously in Romanian in Biserica liturgică [The Liturgical Church], volume supervised by Anca Manolescu (Bucharest: Humanitas, 2005), 177.

${ }^{30}$ Ibidem, 178.
} 


\section{A model of tradition?}

We have seen that André Scrima was detached and partly indifferent to putting his intellectual and spiritual production on paper. On the other hand, we have seen how intensely he endeavours to come to grips with the subtleties of the commented texts and how insistent he is on searching for their rhythm and structure. But, at first sight, his interpretations do not seem to stick to the text. The commentaries, particularly the one on The Letter of John the Foreigner, seem to be rather free. They seem to belong to another level than the one in which the texts reveal themselves. They are far from the texts' explicit vocabulary and theme. After all, someone said, The Letter is only a "pretext" for André Scrima's commentary, a simple starting point. However, Father Scrima dismissed such considerations. For him The Letter acted like a document which requested to be interpreted and which established the rules of its commentary. Genuine hermeneutics, he said, means a permanent confrontation between the original text and the commentary, it means development and return to the text. Interpretation is valid as long as it is supported by the structure of the text, as long as it revolves around its meaning-generating space. In the volume The Time of the Burning Bush there is a specific remark on this matter. "Ever since then (the time of his experience at Antim, my note A.M.), I have said to myself that Father John travelled both with The Philokalia and The Russian Pilgrim in the same way as this one travelled with The Philokalia." 31 The Russian Pilgrim and Father John the Foreigner travelled with the texts of their forerunners, but they particularly travelled within and through these texts. They travelled with the help of these texts.

André Scrima's interpretations also express the commitment of travelling along with the text. They also stand for the methodos type. When engaged in the hermeneutic reading of The Letter of John the Foreigner, he adds a new link to the itinerancy guided by the sacred Text and its commentaries: from The Bible to The Philokalia to The Russian Pilgrim to the Letter of John the Foreigner to its commentary in The Time of the Burning Bush. Thus, we notice the chain of solidary hermits, the filiation of spiritual experience, the enacted tradition. We witness a trans-temporal community, since all of them, regardless of time, take part in the present of the Reality towards/in which they travel.

We thus touch upon what I think is the most important meaning that André Scrima assigns to orality. In fact, all the texts I mentioned above put an uttered word on paper, which was occasioned by the meeting be-

${ }^{31}$ Scrima, Timpul, 159. 
tween a teacher and a disciple or a group of disciples. Seconds after the event that engendered them, all these texts record an experience of knowing, in which the divine Teacher or the teacher/spiritual father addresses a well-configured addressee who stands in front of him. The Gospels put on paper what the apprentices - chosen by Jesus - or their immediate followers retained from the deeds and words of the divine Word. The embodied Word addressed differently to apprentices, crowds, foreigners and adversaries. He attempts to awaken vertical understanding in all of them. $\mathrm{He}$ always addresses them directly and powerfully at public meetings and in private alike. The Philokalia puts on paper words of spiritual experience gathered by hermits from the mouth of their spiritual father who guides their life. Transmitted from one hermit to another in oral form, they are on and off gathered in writing, in florilegia of "words" in order to touch other travellers who need guidance. Even so, these "words" are enclosed in the dialogue between the spiritual father and the apprentice. Let us recall an episode in which the Russian Pilgrim reads The Philokalia guided by his initiator in the Hesychast prayer, who passed into the next life, but appeared in an inspiring dream. Finally, if The Letter of Father John the Foreigner was left, similar to an itinerant's testament, to the group at Antim, its donation was occasioned by their frequent meetings during the short period of time when they stayed together. The "foreign monk" accepted the Antim friends as interlocutors because of their contemplative aspiration. The friends considered him a purveyor of the lively Hesychast tradition. The dialogue took place in the context of this intimate mutual recognition. The letter recapitulates the spiritual journey of the Russian monk. However, for André Scrima, what was written therein remained inseparable from the direct meetings, questions and answers that had been exchanged at Antim, from the presence of the pilgrim Father.

This is a prevailing theme in André Scrima, which he often invokes in different contexts: the handing down of an experience and of spiritual knowledge through vivid dialogue to the interlocutors who mutually acknowledge their quality. In fact, this stands for the handing down of the tradition which, being passed on to other persons, passes through the Zenith that summons them. ${ }^{32}$ If this theme is so important to André Scrima, is it not wise to think that he was also trying to put it in practice as well? Is it not wise to think that his type of speech - occasioned by requests, consisting in orality, spontaneous dialogue with interlocutors whose orientation was well

\footnotetext{
32 Scrima, Timpul, 57: "Tradition (paradosis), the concrete handing down from one person to another, always gives rise to a vertical, zenithal transmission (para, through the «invisible», one may say)".
} 
known - tends to stick to the above-mentioned pattern? Was not his insistence on recording this pattern in the introductions to his written texts a way of catching the reader's eye on it, of imprinting it in the reader? Through his discourse, André Scrima re-enacted a very old model of meeting, of "handing down" spiritual knowledge. Maybe it suggested the manner in which tradition remains alive in a fecund transmission. ${ }^{33}$

${ }^{33}$ Article translated by Dragoş Ivana. 